Tropical Journal of Pharmaceutical Research July 2017; 16 (7): 1465-1472

ISSN: $1596-5996$ (print); 1596-9827 (electronic)

(C) Pharmacotherapy Group, Faculty of Pharmacy, University of Benin, Benin City, 300001 Nigeria.

All rights reserved.

Available online at http://www.tjpr.org

Original Research Article

http://dx.doi.org/10.4314/tjpr.v16i7.2

\title{
Effect of dry-heating with pectin on gelatinization properties of sweet potato starch
}

\author{
Mengxue Chen ${ }^{1}$, Yuanyuan Guo ${ }^{2}$, Fei Li ${ }^{1}$, Jie Zeng ${ }^{1}$ and Guanglei $\mathrm{Li}^{1 *}$ \\ ${ }^{1}$ School of Food Science, Henan Institute of Science and Technology, Xinxiang, 453003, ${ }^{2}$ Xiangnian Food CO., LTD, Nanyang \\ 473000, China \\ *For correspondence: Email: Igl70_hist@163.com; Tel: +863733693693
}

Sent for review: 8 February 2017

Revised accepted: 6 June 2017

\begin{abstract}
Purpose: To evaluate the effect of dry-heating with pectin at different dry heating temperatures, heating times and $\mathrm{pH}$ on the gelatinization properties of sweet potato starch.

Methods: The gelatinization properties of sweet potato starch - pectin blend were analyzed using a rapid viscosity analyzer (RVA), differential scanning calorimeter (DSC), and gel texture analyzer (TPA). Results: The viscosity of the blends of sweet potato starches and pectin increased initially, and then decreased. Viscosity was highest at $120^{\circ} \mathrm{C}$, with a value of $744 \mathrm{cp}$. High viscosity values were also obtained after dry-heating for 2 and $7 \mathrm{~h}$ (540 cp and $639 \mathrm{cp}$, respectively). The enthalpy of the blend declined with increasing heat-treatment temperature from $3.973 \mathrm{~J} / g$ at $0{ }^{\circ} \mathrm{C}$ to $3.021 \mathrm{~J} / g$ at $150{ }^{\circ} \mathrm{C}$. The initial $\left(T_{0}\right)$, peak $\left(T_{p}\right)$, and terminal $\left(T_{c}\right)$ gelatinization temperatures of the blends were all lower than corresponding values at $0{ }^{\circ} \mathrm{C}$. Gelatinization enthalpy values gradually increased with increase in dryheating time and $\mathrm{pH}$ although they were still lower than for the control samples. In addition, as $T_{0}, T_{p}$, and $T_{c}$ values of the blend increased, the gelatinization temperature range became narrower. The hardness and viscosity of the blends increased initially, and then decreased after the dry-heat treatment. The hardness of treated samples was higher than that of control, and peaked at $130{ }^{\circ} \mathrm{C}, 4 \mathrm{~h}$, and $\mathrm{pH}$ 11. The resilience of the blends attained a peak value after $2 \mathrm{~h}$ of dry-heat treatment at $120^{\circ} \mathrm{C}$ and $\mathrm{pH} 9$.

Conclusion: The results show that dry-heating with pectin is an effective way of improving the gelatinization and gel properties of sweet potato starch. This finding is considered significant for the developing of new modified starch from sweet potatoes.
\end{abstract}

Keywords: Sweet potato starch, Pectin, Dry heat, Gelatinization, Viscosity, Hardness, Enthalpy

Tropical Journal of Pharmaceutical Research is indexed by Science Citation Index (SciSearch), Scopus, International Pharmaceutical Abstract, Chemical Abstracts, Embase, Index Copernicus, EBSCO, African Index Medicus, JournalSeek, Journal Citation Reports/Science Edition, Directory of Open Access Journals (DOAJ), African Journal Online, Bioline International, Open-J-Gate and Pharmacy Abstracts

\section{INTRODUCTION}

China is the world's largest producer of sweet potatoes, with a total acreage of $42.72 \%$ of total world acreage, and a total annual output of 79.09 million tons, accounting for $80 \%$ of the world's total sweet potato production (FAO) [1]. Sweet potato starch contents can exceed $30 \%$, and its unique properties are widely used in food, pharmaceutical and chemical industries.
Pectin is a natural plant colloid widely used in the food industry and can be used as a gelling agent, stabilizer, tissue-forming agent, emulsifier, and thickener. It is widely used in food. Pectin is nontoxic and is cheap to produce [2-4]. Starch and edible gum are often used together in the health and pharmaceutical industries to improve product quality or to increase product stability $[5,6]$. A new method used for physical modification of the properties of starches involves dry-heating them (at $120-200{ }^{\circ} \mathrm{C}$ ) with 
pectin at moisture contents below $10 \%$. Dry heat treatment is a promising method for production modified starch: it is simple, safe, and pollutionfree, when compared with chemical methods. Dry heat-denatured starch can be used as a raw material for edible film, and may be used as a green packaging material [7-9]. Previous studies have shown that blending starches with edible gum and subjecting them to dry-heat conditions can effectively improve the physical properties of the starches and hence food quality and stability $[10,11]$.

Lim et al [11] blended ceraceous corn and potato starches with ionic gums and then subjected the blend to dry-heat treatment (after adjusting the $\mathrm{pH})$. Their results showed that there was a crosslinking reaction between the starches and gum (ascribed to an esterification reaction between carboxyl groups in the food gum and hydroxyl groups in the starches). In another study, Li et al [12] carried out in vitro simulations to investigate the slow release performance of a blend of pectin and cassava starches (which had been treated with dry heat) within the small intestines of humans. However, there are, at present, no relevant reports on the effect of dry-heating on the gelatinization properties of sweet potato starch blended with pectin.

The present study investigated the effects of factors such as temperature, treatment time, and $\mathrm{pH}$ on the viscosity, thermodynamics, and gel properties of the blends of sweet potato starch and pectin subjected to dry-heat treatment.

\section{EXPERIMENTAL}

\section{Materials}

Sweet potato starch was provided by the Saiwengfu Agriculture Development Limited Company, Shanghai. Pectin was provided by the Tang Ruisi Food Materials Company (Wichita, Kansas, USA). All the other chemicals used were of analytical grade.

\section{Sample preparation}

Pectin $(1 \mathrm{~g})$ and distilled water $(84 \mathrm{~mL})$ were put into a conical flask and stirred until the pectin was completely dissolved. Sweet potato starch $(49 \mathrm{~g})$ was then added to the uniformly mixed solution, and the mixture was stirred for $1 \mathrm{~h}$ at room temperature $\left(25^{\circ} \mathrm{C}\right)$. The $\mathrm{pH}$ was adjusted to 11 using $0.2 \mathrm{M} \mathrm{HCl}$ or $1 \mathrm{M} \mathrm{NaOH}$. The solution was then dried at $40{ }^{\circ} \mathrm{C}$ in an oven until the moisture content was less than $10 \%$. The residue was then ground and filtered through a sieve with an aperture size of $0.154 \mathrm{~mm}$ so as to obtain the raw blend of starch and pectin. This dried blend was then dry-heated for $4 \mathrm{~h}$ at 130 ${ }^{\circ} \mathrm{C}$ in an oven to obtain the Dry-heat treated sample which was used for further tests.

\section{Evaluation of pasting properties}

The determination of viscosity was mainly based on the method of Zeng et al [13].

A Rapid Visco-Analyzer (RVA) (RVA-Series 4, Newport Scientific Pty Ltd, Warriewood, Australia) was used. Each starch suspension (7\%, w/w; $27 \mathrm{~g}$ total weight) was equilibrated at $50^{\circ} \mathrm{C}$ for $1 \mathrm{~min}$ and then heated to $95^{\circ} \mathrm{C}$ and the rate of $6{ }^{\circ} \mathrm{C} / \mathrm{min}$ and maintained at that temperature for $5 \mathrm{~min}$. The sample was then cooled to $50^{\circ} \mathrm{C}$ at a rate of $6{ }^{\circ} \mathrm{C} / \mathrm{min}$. A paddle rotating speed of $160 \mathrm{rpm}$ was used (the paddle speed was $960 \mathrm{rpm}$ in the first $10 \mathrm{~s}$ ).

\section{Differential scanning calorimetry}

The thermal properties of the potato starchpectin blend were determined according to the method of Zeng et al [13], but with slight modification, using a differential scanning calorimeter (DSC, TA instruments Waters LLC, New Castle,DE, USA) equipped with a thermal analysis data station. Aluminum pans (PerkinElmer) were used for the analysis. Starch samples (1 $\mathrm{mg}$, dried starch basis, dsb) were precisely weighed in the sample pans, mixed with distilled water $(2 \mathrm{mg})$, and sealed. The heating rate was $10{ }^{\circ} \mathrm{C}$ per min over a temperature range of $20-100{ }^{\circ} \mathrm{C}$. Indium and zinc were used as reference standards. Enthalpy change $(\Delta \mathrm{H})$, gelatinization onset temperature $\left(T_{0}\right)$, peak temperature $\left(T_{p}\right)$, and terminal temperature $\left(T_{c}\right)$ were measured. The data were presented as means of three replicates for each starch sample.

\section{Gel properties}

Solutions $(7 \%)$ were prepared by adding the required amount of sample to water $(2 \mathrm{~g})$. A gel was formed after the solution was gelatinized and cooled for $24 \mathrm{~h}$. The properties of the gel were then determined using a gel texture analyzer (in TPA mode). A P 50 probe was used for these tests (in downstream speed mode) at pre-test, test, and post-test speeds of 1.0, 1.0, and $3.0 \mathrm{~mm} / \mathrm{s}$, respectively. The compression ratio and induction force employed were $40 \%$ and auto-5 g, respectively. Tests were conducted at room temperature and the changes in various parameters of the gel (hardness, springiness, gumminess, and chewiness) were assessed. 


\section{Statistical analysis}

Statistical analysis was carried out using SAS 8.0. All measurements were repeated three times. Statistical analysis was carried out using Duncan and Multiple Range Test. Differences were considered significant at $p<0.05$. Data were plotted using Origin 8.0 software (OriginLab, Northampton, MA, USA).

\section{RESULTS}

\section{Viscoelastic properties}

\section{Effect of dry-heat temperature on viscoelastic properties}

A series of experiments were made using different heat-treatment temperatures $(110,120$, 130,140 , and $150{ }^{\circ} \mathrm{C}$ ) while the other test conditions were fixed (the treatment time and $\mathrm{pH}$ of the blend were $4 \mathrm{~h}$ and 11, respectively). The viscosity of the starches was determined in each experiment so that the effect of using different heat-treatment temperatures could be investigated (Figure 1).

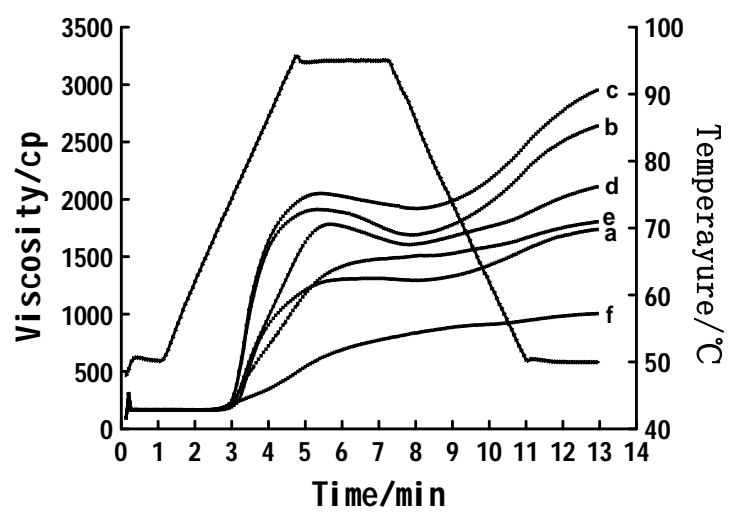

Figure 1: Effect of dry-heat treatment temperature on the RVA spectrum of sweet potato starch. $\left(a=0{ }^{\circ} \mathrm{C} ; \mathrm{b}\right.$ $=110^{\circ} \mathrm{C} ; \mathrm{c}=120^{\circ} \mathrm{C} ; \mathrm{d}=130^{\circ} \mathrm{C} ; \mathrm{e}=140^{\circ} \mathrm{C} ; \mathrm{f}=150$ $\left.{ }^{\circ} \mathrm{C}\right)$

The results on Figure 1 show that heat treatment had significant effect on pasting properties of the blends (sweet potato starch and pectin). The peak, trough, and final viscosities of the blend of sweet potato starch and pectin increased initially, and then fell as the dry-heat treatment temperature was increased. The highest viscosity of the blend was formed at $120^{\circ} \mathrm{C}(744$ $\mathrm{cP})$, which was greater than viscosity at $0^{\circ} \mathrm{C}$. The higher viscosity value could be caused by higher degree of energetic collisions between the starch granules and pectin molecules at higher temperature, leading to higher dissolution of these molecules.
The peak, trough, and final viscosities of the blends formed at $150^{\circ} \mathrm{C}$ were only half of those observed at $0{ }^{\circ} \mathrm{C}$. This suggests that the waterinduced swelling of the starch granules and pectin molecules was inhibited at this temperature, thereby making them difficult to break up. Moreover, the setback values were greater compared with those at $0{ }^{\circ} \mathrm{C}$. This was probably caused by the fact that the forces between the starch and pectin molecules in the amorphous region declined due to the dry-heat treatment. This would result in a loose granular structure, so that the anti-retrogradation of the starches decreased [14]. The breakdown value was closely related to the stability of the starch granules (the greater the breakdown value, the worse the heat stability). The breakdown values after dry-heating at the different temperatures were all higher than that at $0{ }^{\circ} \mathrm{C}$. The peak breakdown value occurred at $110{ }^{\circ} \mathrm{C}$, which indicates that the blend of sweet potato starches and pectin exhibited the worst heat stability at this temperature.

\section{Effect of dry-heat treatment time on the viscoelastic properties}

Viscosity of the potato starch-pectin blend was determined at different heat-treatment times (1, $2,3,4$, and $5 \mathrm{~h}$ ) while the other test conditions were fixed (the treatment temperature and $\mathrm{pH}$ of the blend were $130^{\circ} \mathrm{C}$ and 11 , respectively). The viscosity of the starches was determined in each experiment so that the effect of using different heat-treatment times could be investigated (Figure 2).

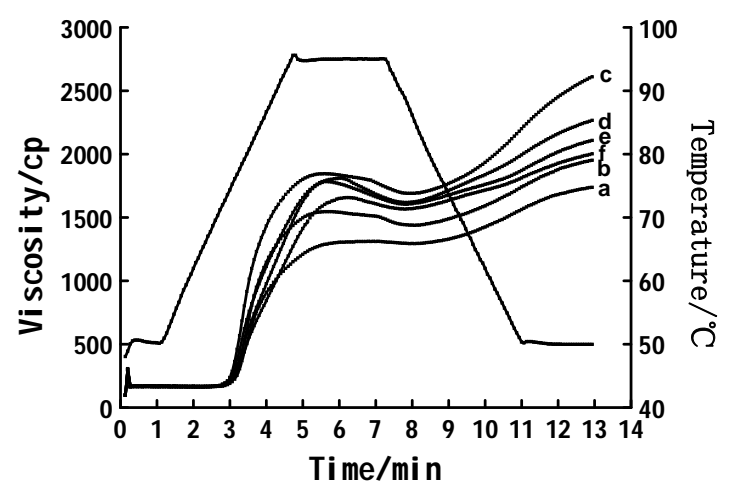

Figure 2: Effect of dry-heat treatment time on the RVA spectrum of sweet potato starch. $(a=0 h ; b=1 \mathrm{~h} ; \mathrm{c}=$ $2 \mathrm{~h} ; \mathrm{d}=3 \mathrm{~h} ; \mathrm{e}=4 \mathrm{~h} ; \mathrm{f}=5 \mathrm{~h}$ )

The results shown on Figure 2 indicate that as the dry-heat treatment time increased, the peak, trough, and final viscosity of the blend increased at first, and then decreased. In addition, the viscosities of the blends were higher than that of control (blend that was not heat-treated). 
Viscosity reached highest values at $2 \mathrm{~h}$. These results suggest that the sweet potato starch underwent a slight cross-linking reaction with the pectin, and that the cross-linking chemical bonds thus formed promoted the stability of the starch. The water swelling and fracture of the starches were effectively inhibited after $5 \mathrm{~h}$ of dry-heat treatment. The breakdown and setback values attained their largest values after dry-heating for $2 \mathrm{~h}$, i.e. the starches were most easily retrograded under these conditions. In addition, gelatinization temperatures increased with time.

\section{Effect of $\mathrm{pH}$ on the viscoelastic properties of potato starch-pectin blend}

The viscosity of potato starch-pectin blend was studied at different $\mathrm{pH}$ values $(5,7,9,11$, and 13) while other test conditions remained fixed (the treatment temperature and time were $130^{\circ} \mathrm{C}$ and $4 \mathrm{~h}$, respectively).

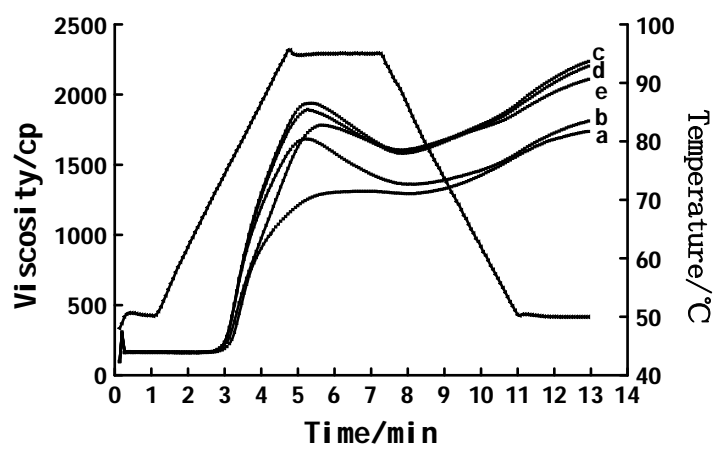

Figure 3: Effect of $\mathrm{pH}$ on the RVA spectrum of sweet potato starch. ( $a=$ control sample; $b=\mathrm{pH} 5 ; \mathrm{c}=\mathrm{pH} 7$ $\mathrm{d}=\mathrm{pH}$ 9; $\mathrm{e}=\mathrm{pH}$ 11)

Dry-heat treatment had significant effects on pasting properties of the blends. The peak, trough, and final viscosities of the blends under dry-heating treatment were increased as a function of $\mathrm{pH}$, when compared to corresponding values for control sample. The results indicate that sweet potato starch underwent cross-linking reaction with pectin under acidic and alkaline conditions. At pH 5, the peak viscosity was 1,678 $\mathrm{CP}$, which was lower than that obtained at other $\mathrm{pH}$ values. This is due to the fact that partial hydrolysis and degradation of the starch occur at acidic $\mathrm{pH}$, a process which blocks the crosslinking reaction [15]. At $\mathrm{pH} 7$, the viscosity of the blend was higher than that obtained at any other $\mathrm{pH}$ value, because hydrolysis and degradation of the starches do not readily occur at this $\mathrm{pH}$. The hydroxyl groups of the starches are activated, allowing them to easily form cross-links chemical bonds with the pectin molecules. With increasing $\mathrm{pH}$, the breakdown value gradually decreases, i.e. the gelatinization of the starches is effectively inhibited. However, in strongly alkaline conditions (pH 13) starch gelatinization occurs, so that it is difficult to determine viscosity of the starch.

\section{Thermal characteristics}

\section{Effect of dry-heat treatment temperature on the thermal characteristics}

The effect of dry heat treatment on the thermal characteristics of the blend was studied at different temperatures $(110,120,130,140$ and $150{ }^{\circ} \mathrm{C}$ ) while other test conditions remained unchanged (the treatment time and $\mathrm{pH}$ of the blend were $4 \mathrm{~h}$ and 11 , respectively). The results obtained are shown on Table 1.

The gelatinization transition temperatures $\left(T_{0}, T_{p}\right.$ and $\left.T_{c}\right)$, gelatinization temperature range $\left(T_{0}-\right.$ $\left.T_{c}\right)$, and the gelatinization enthalpy $(\Delta \mathrm{H})$ of the starch-pectin blend are summarized in Table 1. The initial, peak and terminal gelatinization temperature ( $T_{0}, T_{p}$ and $T_{c}$ respectively) of the blends decreased with the increases in temperature of dry-heat treatment. Moreover, the temperature range over which gelatinization occurred did not increase appreciably. The internal structure of the starch was reorganized due to the dry-heat treatment, while the double helices of the amylopectin became unwound, resulting in starches with loose granular structure. In addition, the binding forces within the crystals became weakened so that the starch chains shortened, while the gelatinization temperatures and gelatinization enthalpy decreased [16].

Table 1: Effect of dry-heat treatment temperature on the thermal properties of sweet potato starch

\begin{tabular}{lccccc}
\hline Variable & $\Delta \mathbf{H}(\mathbf{J} / \mathbf{g})$ & $\mathbf{T}_{\mathrm{o}} /{ }^{\circ} \mathbf{C}$ & $\mathbf{T}_{\mathbf{p}} /{ }^{\circ} \mathbf{C}$ & $\mathbf{T}_{\mathrm{c}} /{ }^{\circ} \mathbf{C}$ & $\mathbf{T}_{\mathbf{o}^{-}} \mathbf{T}_{\mathrm{c}} /{ }^{\circ} \mathbf{C}$ \\
\hline $0^{\circ} \mathrm{C}$ & $3.973 \pm 0.03^{\mathrm{a}}$ & $62.39 \pm 0.06^{\mathrm{b}}$ & $70.01 \pm 0.00^{\mathrm{a}}$ & $79.41 \pm 0.27^{\mathrm{a}}$ & 17.02 \\
$110^{\circ} \mathrm{C}$ & $3.372 \pm 0.12^{\mathrm{b}}$ & $62.93 \pm 0.15^{\mathrm{a}}$ & $69.76 \pm 0.00^{\mathrm{b}}$ & $79.26 \pm 0.16^{\mathrm{b}}$ & 16.36 \\
$120^{\circ} \mathrm{C}$ & $3.245 \pm 0.03^{\mathrm{a}}$ & $61.87 \pm 0.09^{\mathrm{b}}$ & $69.48 \pm 0.00^{\mathrm{c}}$ & $78.97 \pm 0.21^{\mathrm{c}}$ & 17.10 \\
$130^{\circ} \mathrm{C}$ & $3.176 \pm 0.14^{\mathrm{e}}$ & $61.75 \pm 0.14^{\mathrm{b}}$ & $69.07 \pm 0.00^{\mathrm{a}}$ & $78.83 \pm 0.11^{\mathrm{a}}$ & 17.08 \\
$140^{\circ} \mathrm{C}$ & $3.079 \pm 0.05^{\dagger}$ & $61.46 \pm 0.07^{\mathrm{b}}$ & $68.96 \pm 0.00^{\mathrm{e}}$ & $78.79 \pm 0.04^{\mathrm{e}}$ & 17.33 \\
$150^{\circ} \mathrm{C}$ & $3.283 \pm 0.11^{\mathrm{c}}$ & $61.25 \pm 0.11^{\mathrm{b}}$ & $68.75 \pm 0.00^{\dagger}$ & $78.65 \pm 0.17^{\dagger}$ & 17.4 \\
\hline
\end{tabular}

Note: For data in the same column, the same letters represent insignificant differences $(p>0.05)$, while different letters indicate significant differences $(p<0.05)$ 
Effect of dry-heat treatment time on thermal characteristics

The effect of different heat treatment times $(1,2$, 3,4 and $5 \mathrm{~h}$ ) on some thermal characteristics of the potato starch-pectin blend was investigated while other test conditions were fixed (treatment temperature and $\mathrm{pH}$ of the blend were $130{ }^{\circ} \mathrm{C}$ and 11 , respectively).

As shown in Table 2, $T_{0}, T_{\mathrm{c}}$, and $T_{\mathrm{p}}$ values all increased as the dry-heat treatment time was increased. In addition, $T_{0}$ exhibited the most significant change in value after $1 \mathrm{~h}$ of dry-heat treatment $\left(T_{0}\right.$ fell by $1.41{ }^{\circ} \mathrm{C}$, when compared with that of the control sample). The gelatinization temperature range becomes narrower with extended heating (from $17.41^{\circ} \mathrm{C}$ for $1 \mathrm{~h}$, to $17.08^{\circ} \mathrm{C}$ for $4 \mathrm{~h}$ ). The blends showed higher transition temperatures, lower gelation enthalpy and narrower gelatinization temperature range, when compared with corresponding values of these parameters at $0{ }^{\circ} \mathrm{C}$. These results suggest that, with increase in dry heat treatment time, the crystal region of the sweet potato granules was broadened because of the dry-heat treatment, and the binding forces within the starch granules gradually increased.

\section{Effect of $\mathrm{pH}$ on thermal characteristics}

The effect of different $\mathrm{pH}(5,7,9,11$ and 13) on some thermal characteristics of the potato starch - pectin blend was investigated while other test conditions were fixed (treatment temperature and treatment time were fixed at $130{ }^{\circ} \mathrm{C}$ and $4 \mathrm{~h}$, respectively).

Results presented on Table 3 indicate that the gelatinization transition temperature $\left(T_{0}\right.$, and $\left.T_{c}\right)$ of the blends decreased with increase in $\mathrm{pH}$ of the blends. In addition, Also, $T_{0}$ underwent significant change (from $61.04{ }^{\circ} \mathrm{C}$ at $\mathrm{pH} \mathrm{5}$, to $61.75{ }^{\circ} \mathrm{C}$ at $\left.\mathrm{pH} 11\right)$. Gelatinization enthalpy gradually increased, while the gelatinization temperature range was gradually narrowed down. With progressive increase in $\mathrm{pH}$, the dryheat treatment lengthened the molecular chains and broadened the crystal region of the sweet potato starch granules. Thus, the binding forces inside the starch granules gradually increased. As a result, the gelatinization temperature and gelatinization enthalpy of the sweet potato starches increased.

\section{Gel properties}

\section{Effect of dry-heat treatment temperature on gel properties}

The effect of different heat-treatment temperatures $\left(110,120,130,140\right.$, and $\left.150{ }^{\circ} \mathrm{C}\right)$ on the gel properties of the potato starch-pectin blend were determined; while the other test conditions remained unchanged (the treatment time and $\mathrm{pH}$ of the blend were $4 \mathrm{~h}$ and 11 , respectively).

Table 2: Effect of dry-heat treatment time on the thermal properties of sweet potato starch

\begin{tabular}{lccccc}
\hline Variable & $\Delta \mathbf{H}(\mathbf{J} / \mathbf{g})$ & $\mathbf{T}_{\mathbf{o}^{\circ}} \mathbf{C}$ & $\mathbf{T}_{\mathbf{p}} /{ }^{\circ} \mathbf{C}$ & $\mathbf{T}_{\mathbf{c}} /{ }^{\circ} \mathbf{C}$ & $\mathbf{T}_{\mathbf{o}^{-}} \mathbf{T}_{\mathbf{c}} /{ }^{\circ} \mathbf{C}$ \\
\hline $0 \mathrm{~h}$ & $3.973 \pm 0.03^{\mathrm{a}}$ & $62.39 \pm 0.06^{\mathrm{ab}}$ & $70.01 \pm 0.00^{\mathrm{b}}$ & $79.41 \pm 0.27^{\mathrm{a}}$ & 17.02 \\
$1 \mathrm{~h}$ & $2.675 \pm 0.02^{\mathrm{e}}$ & $60.98 \pm 0.29^{\mathrm{bc}}$ & $70.34 \pm 0.00^{\mathrm{e}}$ & $78.39 \pm 0.16^{\dagger}$ & 17.41 \\
$2 \mathrm{~h}$ & $2.814 \pm 0.13^{\mathrm{a}}$ & $61.24 \pm 0.09^{\mathrm{ab}}$ & $70.68 \pm 0.00^{\mathrm{a}}$ & $78.59 \pm 0.21^{\mathrm{e}}$ & 17.35 \\
$3 \mathrm{~h}$ & $3.047 \pm 0.11^{\mathrm{C}}$ & $61.56 \pm 0.14^{\mathrm{ab}}$ & $70.87 \pm 0.00^{\mathrm{c}}$ & $78.67 \pm 0.11^{\mathrm{a}}$ & 17.11 \\
$4 \mathrm{~h}$ & $3.176 \pm 0.14^{\mathrm{a}}$ & $61.75 \pm 0.14^{\mathrm{ab}}$ & $71.34 \pm 0.00^{\mathrm{b}}$ & $78.83 \pm 0.11^{\mathrm{c}}$ & 17.08 \\
$5 \mathrm{~h}$ & $2.820 \pm 0.06^{\mathrm{a}}$ & $61.83 \pm 0.11^{\mathrm{a}}$ & $71.45 \pm 0.00^{\mathrm{a}}$ & $79.01 \pm 0.06^{\mathrm{b}}$ & 17.18 \\
\hline
\end{tabular}

Table 3: Effect of $\mathrm{pH}$ on paste properties of sweet potato starch

\begin{tabular}{|c|c|c|c|c|c|}
\hline Variable & $\Delta \mathrm{H}(\mathrm{J} / \mathrm{g})$ & $\mathrm{T}_{\mathrm{o}} /{ }^{\circ} \mathrm{C}$ & $\mathbf{T}_{\mathrm{p}} /{ }^{\circ} \mathbf{C}$ & $\mathbf{T}_{\mathrm{c}} /{ }^{\circ} \mathbf{C}$ & $\mathrm{T}_{\mathrm{o}}-\mathrm{T}_{\mathrm{c}} /{ }^{\circ} \mathrm{C}$ \\
\hline Control & $3.973 \pm 0.03^{a}$ & $62.39 \pm 0.06^{\mathrm{ab}}$ & $70.01 \pm 0.00^{e}$ & $79.41 \pm 0.27^{a}$ & 17.02 \\
\hline $\mathrm{pH} 5$ & $2.548 \pm 0.04^{e}$ & $61.04 \pm 0.29^{a b}$ & $70.96 \pm 0.00^{d}$ & $78.37 \pm 0.22^{b}$ & 17.33 \\
\hline $\mathrm{pH} 7$ & $2.691 \pm 0.11^{d}$ & $61.28 \pm 0.09^{a}$ & $71.04 \pm 0.00^{c}$ & $78.48 \pm 0.40^{c}$ & 17.20 \\
\hline $\mathrm{pH} 9$ & $2.874 \pm 0.03^{c}$ & $61.53 \pm 0.02^{a}$ & $71.25 \pm 0.00^{\mathrm{D}}$ & $78.65 \pm 0.31^{a}$ & 17.12 \\
\hline $\begin{array}{l}\mathrm{pH} 11 \\
\mathrm{pH} 13^{*}\end{array}$ & $3.176 \pm 0.14^{\mathrm{D}}$ & $61.75 \pm 0.14^{a}$ & $71.34 \pm 0.00^{a}$ & $78.83 \pm 0.11^{e}$ & 17.08 \\
\hline
\end{tabular}

*In strongly alkaline conditions gelatinization of the starches occurs, so that the thermal characteristics of the starches could not be determined 
Table 4: Effect of dry-heat treatment temperature on the thermal properties of sweet potato starch

\begin{tabular}{lcccccc}
\hline Variable & Hardness & Springiness & Cohesiveness & Gumminess & Chewiness & Resilience \\
\hline $0^{\circ} \mathrm{C}$ & $210 \pm 2.81^{\mathrm{e}}$ & $0.92 \pm 0.02^{\mathrm{a}}$ & $0.90 \pm 0.01^{\mathrm{a}}$ & $190 \pm 0.70^{\mathrm{a}}$ & $174 \pm 2.40^{\mathrm{a}}$ & $0.66 \pm 0.01^{\mathrm{a}}$ \\
$110^{\circ} \mathrm{C}$ & $363 \pm 2.50^{\mathrm{c}}$ & $0.92 \pm 0.02^{\mathrm{a}}$ & $0.93 \pm 0.01^{\mathrm{a}}$ & $339 \pm 4.84^{\mathrm{c}}$ & $308 \pm 5.82^{\mathrm{c}}$ & $0.67 \pm 0.01^{\mathrm{a}}$ \\
$120^{\circ} \mathrm{C}$ & $396 \pm 6.11^{\mathrm{b}}$ & $0.94 \pm 0.02^{\mathrm{a}}$ & $0.94 \pm 0.01^{\mathrm{a}}$ & $376 \pm 5.79^{\mathrm{b}}$ & $349 \pm 4.16^{\mathrm{b}}$ & $0.72 \pm 0.02^{\mathrm{a}}$ \\
$130^{\circ} \mathrm{C}$ & $503 \pm 4.14^{\mathrm{a}}$ & $0.92 \pm 0.03^{\mathrm{a}}$ & $0.84 \pm 0.01^{\mathrm{b}}$ & $420 \pm 4.26^{\mathrm{a}}$ & $392 \pm 5.50^{\mathrm{a}}$ & $0.69 \pm 0.01^{\mathrm{a}}$ \\
$140^{\circ} \mathrm{C}$ & $307 \pm 1.72^{\mathrm{a}}$ & $0.58 \pm 0.11^{\mathrm{b}}$ & $0.39 \pm 0.06^{\mathrm{c}}$ & $106 \pm 9.47^{\mathrm{e}}$ & $64 \pm 2.17^{\mathrm{e}}$ & $0.26 \pm 0.01^{\mathrm{b}}$ \\
$150^{\circ} \mathrm{C}$ & $106 \pm 0.19^{\dagger}$ & $0.42 \pm 0.04^{\mathrm{c}}$ & $0.27 \pm 0.03^{\mathrm{a}}$ & $27 \pm 0.73^{\dagger}$ & $11 \pm 0.82^{\dagger}$ & $0.09 \pm 0.02^{\mathrm{c}}$ \\
\hline
\end{tabular}

Table 5: Effect of dry-heat treatment time on the thermal properties of sweet potato starch

\begin{tabular}{lcccccc}
\hline Variable & Hardness & Springiness & Cohesiveness & Gumminess & Chewiness & Resilience \\
\hline $0 \mathrm{~h}$ & $210 \pm 2.81^{\mathrm{t}}$ & $0.92 \pm 0.02^{\mathrm{a}}$ & $0.90 \pm 0.01^{\mathrm{a}}$ & $190 \pm 0.70^{\mathrm{h}}$ & $174 \pm 2.40^{\mathrm{e}}$ & $0.66 \pm 0.01^{\mathrm{a}}$ \\
$1 \mathrm{~h}$ & $312 \pm 2.92^{\mathrm{e}}$ & $0.92 \pm 0.01^{\mathrm{a}}$ & $0.90 \pm 0.04^{\mathrm{a}}$ & $272 \pm 5.41^{\mathrm{a}}$ & $251 \pm 5.36^{\mathrm{c}}$ & $0.68 \pm 0.02^{\mathrm{a}}$ \\
$2 \mathrm{~h}$ & $455 \pm 4.10^{\mathrm{c}}$ & $0.95 \pm 0.03^{\mathrm{a}}$ & $0.90 \pm 0.01^{\mathrm{a}}$ & $407 \pm 3.34^{\mathrm{c}}$ & $393 \pm 5.67^{\mathrm{b}}$ & $0.72 \pm 0.03^{\mathrm{a}}$ \\
$3 \mathrm{~h}$ & $567 \pm 4.55^{\mathrm{a}}$ & $0.93 \pm 0.02^{\mathrm{a}}$ & $0.91 \pm 0.03^{\mathrm{a}}$ & $525 \pm 5.84^{\mathrm{a}}$ & $498 \pm 2.68^{\mathrm{a}}$ & $0.72 \pm 0.03^{\mathrm{a}}$ \\
$4 \mathrm{~h}$ & $503 \pm 4.14^{\mathrm{b}}$ & $0.92 \pm 0.03^{\mathrm{a}}$ & $0.84 \pm 0.01^{\mathrm{b}}$ & $420 \pm 4.26^{\mathrm{b}}$ & $392 \pm 5.50^{\mathrm{b}}$ & $0.69 \pm 0.01^{\mathrm{a}}$ \\
$5 \mathrm{~h}$ & $371 \pm 3.51^{\mathrm{a}}$ & $0.83 \pm 0.02^{\mathrm{b}}$ & $0.71 \pm 0.02^{\mathrm{c}}$ & $253 \pm 4.51^{\mathrm{e}}$ & $206 \pm 4.18^{\mathrm{a}}$ & $0.59 \pm 0.04^{\mathrm{b}}$ \\
\hline
\end{tabular}

Table 6: Effect of $\mathrm{pH}$ on the paste properties of sweet potato starch

\begin{tabular}{lcccccc}
\hline Variable & Hardness & Springiness & Cohesiveness & Gumminess & Chewiness & Resilience \\
\hline A & $210 \pm 2.81^{\mathrm{a}}$ & $0.92 \pm 0.02^{\mathrm{a}}$ & $0.90 \pm 0.01^{\mathrm{a}}$ & $190 \pm 0.70^{\mathrm{a}}$ & $174 \pm 2.40^{\mathrm{a}}$ & $0.66 \pm 0.01^{\mathrm{a}}$ \\
pH 5 & $367 \pm 4.53^{\mathrm{c}}$ & $0.90 \pm 0.03^{\mathrm{a}}$ & $0.93 \pm 0.00^{\mathrm{a}}$ & $343 \pm 4.65^{\mathrm{b}}$ & $315 \pm 3.82^{\mathrm{b}}$ & $0.70 \pm 0.00^{\mathrm{a}}$ \\
pH 7 & $363 \pm 5.95^{\mathrm{c}}$ & $0.91 \pm 0.05^{\mathrm{a}}$ & $0.92 \pm 0.05^{\mathrm{a}}$ & $325 \pm 2.73^{\mathrm{c}}$ & $302 \pm 5.79^{\mathrm{c}}$ & $0.69 \pm 0.07^{\mathrm{a}}$ \\
pH 9 & $383 \pm 1.89^{\mathrm{b}}$ & $0.90 \pm 0.00^{\mathrm{a}}$ & $0.92 \pm 0.01^{\mathrm{a}}$ & $348 \pm 3.20^{\mathrm{b}}$ & $314 \pm 4.94^{\mathrm{b}}$ & $0.73 \pm 0.02^{\mathrm{a}}$ \\
pH 11 & $503 \pm 4.14^{\mathrm{a}}$ & $0.92 \pm 0.03^{\mathrm{a}}$ & $0.84 \pm 0.01^{\mathrm{b}}$ & $420 \pm 4.26^{\mathrm{a}}$ & $392 \pm 5.50^{\mathrm{a}}$ & $0.69 \pm 0.01^{\mathrm{a}}$ \\
pH 13* & & & & & &
\end{tabular}

${ }^{*}$ In strongly alkaline conditions gelatinization of the starches occurs, so that the gel properties of the starches could not be determined

Table 4 shows variations in gel properties of the potato sharch-pectin blend with changes in dryheat treatment temperature. It can be seen that as the dry-heat temperature was gradually increased, there were initial increases in hardness, gumminess, and chewiness of the blend which were followed by decreases in these parameters. The hardness, gumminess, and chewiness attained peak values at $130{ }^{\circ} \mathrm{C}$. Optimal springiness and resilience appeared at $120^{\circ} \mathrm{C}$, but both indices gradually declined with increasing temperature.

\section{Effect of dry-heat treatment time on the gel properties}

The results obtained on the effect of dry heat treatment times $(1,2,3,4$ and $5 \mathrm{~h})$ on gel characteristics of potato starch - pectin blend are shown on Table 5.

The hardness, gumminess, and chewiness of the blends first increased and then decreased with increase in dry-heat treatment time. The highest values for hardness, gumminess, chewiness, and resilience were obtained at $3 \mathrm{~h}$. These results suggest that the forces needed for sample modification are highest under such conditions (the binding forces in the samples are very strong, resilience is very high, so more energy is needed for modification and the resilience is the best).

\section{Effect of $\mathrm{pH}$ on gel properties}

Table 6 shows the effect of $\mathrm{pH}$ on gel properties of the potato starch - pectin blend at fixed temperature $\left(130{ }^{\circ} \mathrm{C}\right)$ and dry heat treatment period $(4 \mathrm{~h})$.

The hardness, gumminess, and chewiness of the blend of sweet potato starches and pectin increased as the $\mathrm{pH}$ was increased. The effect of $\mathrm{pH}$ on springiness of the blend was least at $\mathrm{pH} 9$, while the best resilience was obtained at this $\mathrm{pH}$.

\section{DISCUSSION}

Modified starches have a wide scope of applications. After modification, the starches have improved properties when compared to properties of the native starches. Modification may also confer new and desirable properties on starch. Some investigations have been carried out on the gelatinization properties, rheological behavior and film-forming characteristics of dry heat-modified starches. However, investigation on dry-heat modification of starches using gums have focused mainly on the effects of this treatment on gelatinization. Lim et al [11] blended corn and potato starches with ionic gums under 
dry-heat conditions at $130{ }^{\circ} \mathrm{C}$ and at different periods of treatment times. They found that the gelatinization viscosity of the blends increased after dry-heat treatment while the transparency of the blends declined. Like cross-linking agents, ionic gums promote esterification between starches and gums. Therefore, this method can be utilized for the preparation of modified starches with specific functions. Chung et al [5] studied the effect of xanthan gum on the crosslinking reaction between rice starches and phosphates under dry-heat conditions. Their results showed that xanthan gum was advantageous to the cross-linking reaction. In addition, it was proposed that the viscosity of the starches changed due to breakage of hydrogen bonds between starch molecules during dry-heat treatment, while further heating could result in the breakdown of glucosidic bonds. It has been reported that when rice starches of different amylose contents were significant changes in the gelatinization properties of the starches [16]. Their results also showed that the tensile strength of the basilemma of the modified starches increased, while their oxygen and gas permeabilities declined. In the present study, the effects of dry heat treatment conditions such as temperature, time and $\mathrm{pH}$ on the gelatinization, thermodynamics, and gel properties of the dryheated potato starch-pectin blend were systematically investigated. The results showed the viscosity of the blends increased after dryheat treatment under different $\mathrm{pH}$ values, and at different temperatures and different treatment times. This implies there was extensive crosslinking between the potato starch and pectin. These results are consistent with the findings of Lim et al [11] who reported that the viscosity of blends of corn and potato starch with ionic gums increased under dry-heat treatment, while lactide was produced due to the reaction between the starch and pectin. However, the results of the present study are not in agreement with those of Yuan et al who found that (that the peak the peak values of viscosity and retrogradation of a blend of edible gums and corn starches decreased after dry-heat treatment while the gelatinization temperature of the starches increased.

\section{CONCLUSION}

The results obtained in this study demonstrate that the gelatinization properties of a blend of potato starch and pectin are influenced by dryheat treatment. In particular, decreases in breakdown and setback values indicate that dryheat modification with pectin enhances the stability of the starch. The results suggest that the internal structure of the starch is reorganized by the treatment, resulting in broadening of the crystal region of the starch granules, and increase in the enthalpy and intermolecular binding forces as a function of increases in time and $\mathrm{pH}$. Dry-heat modification with pectin enhances the hardness, gumminess, and chewiness of sweet potato starch. These results are considered significant in that they provide a theoretical basis for improving the functional performance of starches, especially in the deep processing of sweet potato starch.

\section{DECLARATIONS}

\section{Acknowledgement}

This study was funded by Program for Innovative Research Team and Major Breeding Project of Henan Institute of Science and Technology (no. 2013ZD04) and scientific and technological project of Henan Province (no. 172102110164).

\section{Conflict of Interest}

No conflict of interest associated with this work.

\section{Contribution of Authors}

The authors declare that this work was done by the authors named in this article and all liabilities pertaining to claims relating to the content of this article will be borne by them.

\section{Open Access}

This is an Open Access article that uses a funding model which does not charge readers or their institutions for access and distributed under the terms of the Creative Commons Attribution License (http://creativecommons.org/licenses/by/ 4.0) and the Budapest Open Access Initiative (http://www.budapestopenaccessinitiative.org/rea d), which permit unrestricted use, distribution, and reproduction in any medium, provided the original work is properly credited.

\section{REFERENCES}

1. Xiao $H X$, Lin PL, Xia XJ, Li HL, Li LZ, Wu WG. Rheological properties of sweet potato starch before and after denaturalization. J Cent South Univ Technol, 2008; 15(1): 500-505.

2. Lui L, Fishman ML, Kost J, Hicks K. Pectin-based systems for colon-specific drug delivery via oral route. Biomaterials , 2003; 24(19): 3333-3343

3. Watts $P$, Smith A. PecSys: In situ gelling system for optimised nasal drug delivery, Expert Opin, Drug Deliv, 2009; 6(5):543.-552 
4. Faten I. Abou El Fadl. Nabila A. Maziad. Radiation syntheses of Pectin/acrylamide (PEC/PAM) and Pectin/Diethylaminoethylmethacrylate (PEC/DEAMA) hydrogels as drug delivery systems. Radianal Nucl Chem, 2015; 303(1): 623-630.

5. Chung HJ, Min D, Kim JY, Lim ST. Effect of minor addition of xanthan on cross-linking of rice starches by dry heating with phosphate salts. J Appl Polym Sci, 2007; 105(4): 2280-2286.

6. Baranowska HM, Sikora M, Kowalaki S, Tomasik $P$. Interactions of potato starch with selected polysaccharide hydrocolloids as measured by low-filed NMR. Food Hydrocolloids, 2008; 22(2): 336-345.

7. Lu SL, Xu XL, Zhou GH, Zhu ZY, Meng Y, Sun YM. Effect of starter cultures on microbial ecosystem and biogenic amines in fermented sausage. Food Control, 2010; 21(4): 444-449.

8. Hu P, Zhou GH, Xu XL, Li CB, Han YQ. Characterization of the predominant spoilage, bacteria in sliced vacuumpacked cooked ham based on $16 S$ rDNA-DGGE. Food Control, 2009; 20(2): 99-104.

9. Hovda MB, Lunestad BT, Sivertsvik M. Chod (Gadus morhua) by PCR-DGGE of conserved 16S rRNA gene regions. Int $J$ Food Microbiol, 2007; 117(1): 68-75.

10. Lim ST, Han JA, Lim HS, Bemiller JN. Modification of starch by dry heating with ionic gums. Cereal Chem. 2002; 79(5); 601-606.
11. Lim ST, BeMiller JN, Lim ST. Effect of dry heating with ionic gums at controlled $\mathrm{pH}$ on starch paste viscosity. Cereal Chem, 2003; 80(2): 198-202.

12. Li JB, LiC, Yang Y, He ZW, Hang FX. Preparation of intestinal targeted drug carrier by modified pectin/starch. Modern Chemical Industry, 2015; 35(9): 97-100(in chinese).

13. Zeng J, Gao HY, Li GL. Effect of sucrose esters on the physicochemical properties of wheat starch. Trop $J$ Pharm Res, 2013; 12(5): 685-690.

14. Li Y, Zhang H, Shoemaker CF, Xu ZT, Zhu SZ, Zhong F. Effect of dry heat treatment with xanthan on waxy rice starch. Carbohydr polym, 2013; 92(2): 1647-1652.

15. Chiu CW, Schiermeyer E, Thomas DJ. Thermally inhibited starches and flours and process for their production. U.S. patent: 5725675, 1998.

16. Jiranuntakul W, Puttanlek C, Rungsardthong V, Punchaarnon S, Uttapap D. Microstuctural and physicochemical properties of heat-moisture treated waxy and normal starches, J Food Eng, 2011; 104(2): 246-258.

17. Li Y, Shoemaker CF, Ma JG, Shen XR, Zhong F. Paste viscosity of rice starches of different amylase content and carboxymethylcellulose formed by dry heating and the physical properties of their films. Food Chem, 2008; 109(3): 616-623. 